\title{
PERAN PESANTREN SEBAGAI BASIS PENANAMAN NILAI KARAKTER RELIGIUS DAN KEMANDIRIAN DI PESANTREN AL-ITTIHAD KABUPATEN CIANJUR JAWA BARAT
}

\author{
Taqiyudin $^{1}$, Y. Syafe'i, R ${ }^{2}$, Fathurrohman, $A^{3}$ \\ Universitas Islam Nusantara \\ Taqiyun@gmail.com
}

\begin{abstract}
ABSTRAK
Pesantren merupakan lembaga pendidikan yang mempunyai sejarah panjang dan unik. Secara historis, pesantren termasuk pendidikan Islam yang paling awal dan masih bertahan sampai sekarang. Persoalan karakter menjadi bahan pemikiran sekaligus keprihatinan bersama karena masyarakat Indonesia saat ini sedang mengalami krisis karakter.

Penelitian ini bertujuan untuk mendeskripsikan pelaksanaan nilai religius dan kemandirian dalam pendidikan karakter di Al-Ittihad Kabupaten Cianjur.

Jenis penelitian ini adalah penelitian deskriptif kualitatif. Subjek penelitian adalah Ustadz dan santri. Penelitian dilaksanakan pada bulan Agustus 2020. Teknik pengumpulan data yang digunakan adalah observasi, wawancara, dan dokumentasi. Data dianalisis dengan menggunakan model Milles and Huberman yaitu reduksi data, display data, dan penarikan kesimpulan. Teknik pemeriksaan keabsahan data dengan triangulasi sumber dan teknik.

Hasil penelitian menunjukan bahwa: (1) persepsi tentang pentingnya nilai religius dan kemandirian dalam pendidikan karakter merupakan salah satu sumber yang melandasi pendidikan karakter dan sangat penting untuk ditanamkan kepada siswa sejak dini karena dengan bekal keagamaan yang yang kuat sejak dini akan memperkokoh pondasi moral siswa di masa depan. (2) Peran pesantren dalam mendukung pelaksanaan nilai karakter religius dan kemandirian dalam pendidikan karakter yaitu menyediakan fasilitas-fasilitas yang dibutuhkan, memberikan izin kepada guru untuk mengadakan suatu program kegiatan, mendukung adanya kegiatan-kegiatan yang ada di luar pesantren, serta memberikan teladan yang baik bagi santri. (3) Pelaksanaan nilai religius dan kemandirian dalam penanaman karakter melalui program pengembangan diri yang terdiri dari kegiatan-kegiatan rutin yang ada di pesantren, kegiatan spontan yang dilakukan guru pada santri, keteladanan yang diberikan guru, dan pengkondisian pesantren yang diciptakan sedemikian rupa.

Kata kunci: nilai karakter, karakter religius, karakter kemandirian
\end{abstract}

\section{ABSTRACT}

Pesantren is an educational institution that has a long and unique history. Historically, pesantren were among the earliest Islamic educations and still survive today. The issue of character is a matter of thought as well as a common concern because the Indonesian people are currently experiencing a character crisis.

This study aims to describe the implementation of religious values and independence in character education in the Al-Ittihad Islamic Boarding Schools in Cianjur Regency.

\footnotetext{
${ }^{1}$ Mahasiswa Pascasarjana UNINUS Bandung

${ }^{2}$ Dosen Pascasarjana PAI UNINUS Bandung

${ }^{3}$ Dosen Pascasarjana PAI UNINUS Bandung
} 
This type of research is a qualitative descriptive study. The research subjects were Ustadz and ssantri. The research was conducted in August 2020. The data collection techniques used were observation, interviews, and documentation. Data were analyzed using the Milles and Huberman model, namely data reduction, data display, and conclusion drawing. The technique of checking the validity of the data is by means of triangulation of sources and techniques.

The results showed that: (1) the perception of the importance of religious values and independence in character education is one of the sources that underlie character education and it is very important to be instilled in students from an early age because strong religious provisions from an early age will strengthen the moral foundations of students in future. (2) The role of pesantren in supporting the implementation of religious character values and independence in character education, namely providing the facilities needed, giving permission to teachers to carry out an activity program, supporting existing activities outside the pesantren, and providing good role models. for students. (3) The implementation of religious values and independence in instilling character through self-development programs consisting of routine activities at the pesantren, spontaneous activities by teachers to students, exemplary provided by the teacher, and conditioning of the pesantren which are created in such a way

Keywords: character value, religious character, independence character 


\section{PENDAHULUAN}

Menurut Rahim (2001: 28), pesantren merupakan sebuah lembaga pendidikan tertua yang melekat dalam perjalanan kehidupan Indonesia sejak ratusan tahun yang silam. Pesantren merupakan lembaga pendidikan yang dapat dikategorikan sebagai lembaga unik dan punya karakteristik tersendiri yang khas, sehingga saat ini menunjukkan kapabilitasnya yang cemerlang melewati berbagai episode zaman dengan pluralitas polemik yang dihadapinya.

Pesantren dapat dibedakan kepada dua macam, yaitu pesantren tradisional dan pesantren modern. Sistem pendidikan pesantren tradisional sering disebut sistem salafi, yaitu sistem yang tetap mempertahankan pengajaran kitab-kitab Islam klasik sebagai inti pendidikan di pesantren. pesantren modern merupakan sistem pendidikan yang berusaha mengintegrasikan secara penuh sistem tradisional dan sistem sekolah formal (seperti madrasah). (Ahmad Tafsir, 1991: 193194).

Kemajuan suatu bangsa terletak pada karakter yang dimiliki bangsa tersebut. Karakter merupakan hal yang sangat penting dan mendasar. Karakter adalah mustika hidup yang membedakan antara manusia dengan hewan. Manusia yang tidak berkarakter dikatakan sebagai manusia yang sudah melampui batas. Orang yang berkarakter kuat dan baik secara individual dan sosial ialah yang memiliki akhlak, moral dan budi pekerti yang baik.( Zubaedi, 2012: 1)

Apabila suatu bangsa telah kehilangan karakternya, maka sesuatunya telah hilang, berbeda dengan kehilangan harta benda tidak ada sesuatu yang hilang, begitupula jika kesehatan hilang baru ada sesuatu yang hilang tetapi jika karakter telah hilang maka hilanglah semuanya hal ini sebagaimana dikemukakan oleh William Franklin Graham sebagai berikut: When Wealth is lost nothing lost, when health lost something lost, when character lost everything is lost. (Marwan, 2015: 60)

Persoalan karakter menjadi bahan pemikiran sekaligus keprihatinan bersama karena masyarakat Indonesia saat ini sedang mengalami krisis karakter. Krisis ini ditandai dengan maraknya tindakan kriminalitas, seperti tawuran antara pelajar, meningkatnya pergaulan bebas, maraknya angka kekerasan anak-anak dan remaja, pelecehan seksual, maraknya geng motor dan begal yang seringkali menjurus pada tindakan kekerasan yang meresahkan masyarakat, korupsi mewabah dan merajalela dan merambah pada semua sektor kehidupan masyarakat, bahkan menjerumus pada tindakan pembunuhan. Fenomena tersebut jelas telah mencoreng citra pelajar dan lembaga pendidikan, karena banyak orang yang berpandangan atau mempunyai prespektif bahwa kondisi demikian berawal pada apa yang kemudian dihasilkan oleh dunia pendidikan.

Atas kondisi demikian, semua pihak sepakat mengatasi persoalan kemorosotan pada dimensi karakter ini. Sebenarnya, persoalan karakter atau moral tidak sepenuhnya terabaikan oleh lembaga pendidikan. Akan tetapi, fenomena yang terjadi menunjukkan bahwa ada kegagalan pada institusi pendidikan untuk menumbuhkan manusia Indonesia yang berkarakter dan berakhlak mulia.

Karakter positif seseorang akan mengangkat status pada derajat yang tinggi dan mulia bagi dirinya. Kemulian seseorang terletak pada karakternya. Aristoteles melihat karakter sebagai kemampuan melakukan tindakan yang baik dan bermoral, Psikolog Frank Pittman yang dikutip Zubaedi mengamati bahwa kestabilan hidup bergantung pada karakter (Zubaedi, 2012: $6)$.

Untuk mewujudkan hal tersebut, upaya yang tepat untuk mengubah perilaku diri seseorang agar menjadi pribadi yang kuat dan unggul adalah melalui jalur pendidikan khususnya pendidikan pesantren, karena pendidikan pesantren sangat mempunyai arti yang sangat penting bagi kehidupan bermasyarakat saat ini.

Berdasarkan hal tersebut penulis yang terkait tentang implementasi nilai-nilai pendidikan karakter adalah bahwa pelaksanaan pendidikan karakter belum sepenuhnya atau seluruhnya terimplementasi dengan baik dan masih ada beberapa hambatan. Sebagian orang sudah memiliki kepribadian yang baik seperti melakukan shalat dhuhur dan ashar berjamaah di masjid. Namun belum seluruhnya, masih banyak terdapat sebagian orang yang memiliki perilaku yang menyimpang seperti, suka melawan kepada orang tua, suka berbohong atau tidak jujur, tidak disiplin dan cenderung berprilaku negatif. Dengan kata lain, perilaku seseorang masih perlu pembenahan dan pengembangan.

Atas dasar latar belakang tersebut, penulis melakukan penelitian dengan judul yakni "Peran Pesantren Sebagai Basis Penanaman Nilai Karakter Religius dan Kemandirian di Pesantren Al-Ittihad Cianjur". Oleh sebab itu, penulis ingin mengetahui tentang: 
a. Bagaimana proses penanaman nilai karakter di Pesantren Al-Ittihad Kabupaten Cianjur Jawa Barat?

b. Bagaimana hasil penanaman nilai karakter religius dan kemandirian di Pesantren Al-Ittihad Kabupaten Cianjur Jawa Barat?

\section{METODE PENELITIAN}

Penelitian ini dilaksanakan dengan menggunakan pendekatan kualitatif. Metode yang digunakan analisis deskriptif. Lokasi dan sumber data penelitian di Pesantren Al-Ittihad Kabupaten Cianjur Jawa Barat.. Teknik dan instrumen penelitian menggunakan observasi,wawancara dan dokumentasi. Sedangkan teknik analisis dilakukan melalui reduksi data,display data dan penarikan kesimpulan. Pengecekan keabsahan data menggunakan perpanjangan kehadiran.

\section{KAJIAN TEORI}

\section{Pesantren}

Menurut Zuhriy (2011:288):

Pesantren adalah salah satu institusi yang unik dengan ciri khas yang sangat kuat dan lekat. Peran yang diambil adalah upaya-upaya mencerdaskan bangsa yang telah turun temurun tanpa henti. Pesantrenlah yang memberikan pendidikan pada masa-masa sulit, masa perjuangan melawan penjajah dan merupakan pusat studi yang tetap bertahan sampai masa kini.

Tujuan pendidikan pesantren menurut Zamakhsyari Dhofier (Zuhriy, 2011: 288) bukanlah untuk mengejar kepentingan kekuasaan, uang atau hal-hal duniawi, tetapi ditanamkan kepada mereka bahwa belajar adalah semata-mata kewajiban dan pengabdian kepada Tuhan. Oleh karena itu, sebagai salah satu lembaga pendidikan, pesantren juga mempunyai tanggung jawab yang besar dalam membentuk karakter para santri.

Menurut Geertz (1960), pengertian pesantren diturunkan dari bahasa India shastri yang berarti para ilmuwan hindu yang pandai menulis. Maksudnya, pesantren adalah tempat bagi orang-orang yang pandai membaca dan menulis. Geertz menganggap bahwa pesantren dimodifikasi dari para Hindu (Wahjoetomo, 1997: 70).

Dari pengertian di atas maka dapat disimpulkan bahwa pesantren adalah lembaga pendidikan Islam dengan sistem asrama, Kyai sebai sentral figurnya, masjid sebagai titik pusat yang menjiwai. Adapun isi dari pesantren itu adalah pada pendidikannya. pesantren memberikan pendidikan rohani yang sangat berharga kepada para santrinya sebagi kader-kader muballigh dan pemimpin umat. Dalam pesantren itu terjalin jiwa yang kuat yang sangat menentukan cara pandang hidup para santrinya.

\section{Nilai}

Menurut Steeman (dalam Adisusilo, 2013:56):

nilai adalah sesuatu yang memberi makna dalam hidup, yang memberi acuan, titik tolak dan tujuan hidup. Nilai adalah sesuatu yang dijunjung tinggi, yang dapat mewarnai dan menjiwai tindakan seseorang. Nilai itu lebih dari sekedar keyakinan, nilai selalu menyangkut pola pikir dan tindakan, sehingga ada hubungan yang amat erat antara nilai dan etika.

Menurut Tyler (1973:7) nilai adalah suatu objek, aktivitas atau idea yang dinyatakan oleh individu yang mengendalikan pendidikan dalam mengarahkan minat, sikap, dan kepuasan. Selanjutnya dijelaskan bahwa sejak manusia belajar menilai suatu objek, aktivitas dan ide sehingga objek ini menjadi pengatur penting minat, sikap dan kepuasan. Oleh karena itu, sekolah harus menolong siswa menemukan dan menguatkan nilai yang bermakna dan signifikan bagi siswa dalam memperoleh kebahagiaan personal dan memberi kontribusi positip terhadap masyarakat.

Berdasarkan definisi di atas, dapat dikatakan bahwa nilai merupakan keyakinan dalam menentukan suatu pilihan untuk menjadikan hidup seseorang menjadi lebih baik. Dengan menerapkan aturan-aturan atau norma-norma yang berlaku pada suatu daerah sebagai acuan untuk memperoleh kehidupan yang lebih baik.

\section{Karakter}

Menurut Thomas Lickona (1991:51) karakter adalah sebagai berikut:

"A reliable inner disposition to respond to situations in a morally good way." Selanjutnya, Lickona menambahkan, "Character so conceived has three interrelated parts: moral knowing, moral feeling, and moral behavior".

Karakter mulia (good character), dalam pandangan Lickona, meliputi pengetahuan tentang kebaikan (moral knowing), lalu menimbulkan komitmen (niat) terhadap kebaikan (moral feeling), dan akhirnya benar-benar melakukan suatu kebaikan (moral behavior). Dengan kata lain, karakter mengacu kepada serangkaian sikap (attitudes), pengetahuan (cognitives), dan motivasi (motivations), serta perilaku (behaviors) dan keterampilan (skills).

\section{Karakter Kemandirian}

Menurut Yamin dan Jamilah (2013:65)" 
karakter kemandirian merupakan suatu sikap individu yang diperoleh secara kumulatif selama masa perkembangan, dimana individu akan terus belajar untuk mandiri dalam menghadapi berbagai situasi di lingkungan, sehingga individu tersebut pada akan mampu berfikir dan bertindak sendiri.

Poerwadarminta (1976:513) menyebutkan pengertian kemandirian didalam kamus besar bahasa Indonesia disebutkan bahwa kemandirian adalah keadaan dapat berdiri sendiri, keadaan dapat mengurus atau mengatasi kepentingan sendiri tanpa tergantung kepada orang lain. Sedangkan otonomi adalah kebebasan atau kemampuan untuk bertindak menurut prioritasprioritas atau prinsip-prinsip sendiri, tanpa dibingungkan oleh paksaan-paksaan dari luar atau tekanan-tekanan dari dalam seperti hasrat-hasrat yang tidak diinginkan tetapi tidak terkuasai. Asihwardji (1996:27)

Berdasarkan pendapat di atas, otonomi adalah mengatur diri sendiri atau untuk memutuskan cara sendiri. Hidup mandiri adalah hidup sesuai dengan keinginan dasar seseorang atau nilai-nilai. Dengan dasar keinginan yang diinginkannya demi dirinya sendiri.

\section{Karakter Religius}

Religius merupakan salah satu nilai dalam pendidikan karakter dideskripsikan oleh Kemendiknas (2010: 27) sebagai sikap dan perilaku yang patuh dalam melaksanakan ajaran agama yang dianut, dan hidup rukun dengan pemeluk agama lain, toleran terhadap pelaksanaan ibadah agama lain.

Selanjutnya, Akhmad Muhaimin Azzet (2011: 88) mengungkapkan bahwa hal yang semestinya dikembangkan dalam diri peserta didik adalah terbangunnya pikiran, perkataan, dan tindakan siswa yang didasarkan pada nilai-nilai ketuhanan atau yang bersumber dari ajaran agama yang dianutnya oleh karena itu diharapkan peserta didik benar-benar memahami dan mengamalkan ajaran dalam kehidupan sehari-hari.

\section{HASIL DAN PEMBAHASAN \\ 1.Proses Pembentukaan Karakter Santri di Pesantren Al-Ittihad Cianjur}

Proses adalah sebagai tahap kunci utama untuk mencapai tujuan atau kesuksesan. Proses di sini berjalan melalui kegiatan-kegiatan keagamaan yang akan menumbuhkan sifat atau karakter yang baik serta ber akhalak mulia dan berbudi pekerti baik dalam perbuatan dan setiap perkataan. Di dalam kegiatan-kegitan agama ini akan menjadikan santri secara luas akan lebih memahami Islam.

Proses pembentukan karakter Religius dan Kemandirian santri Pesantren Al-Ittihad sebagai berikut:

1) Karakter Religius, membentuk karakter Religius santri dilakukan dengan beberapa tahap yaitu a) memberikan kesadaran kewajiban sebagai umat islam, pengetahuan tentang hukum-hukum islam, akidah dan akhlak. b) memberikan pengarahan tentang kesadaran akan ibadah wajib dan sunnah, cinta ilmu dan bersih hati. c) memberikan pengarahan untuk membiasakan diri untuk melaksanakan kewajiban sebagai umat islam, bertaubat, berfikir sebelum berbicara, merenungi dosa-dosa, menghukum diri sendiri jika melakukan kesalahan. 2) Karakter Kemandirian, membentuk karakter mandiri pada santri dilakukan dengan jalan: a) memberikan pengetahuan secara detail dari kegiatan pembelajaran. b) memberikan pengarahan tentang kemampuan menganalisis dan menyimpulkan bahwa kegiatan sesuai dengan kebutuhan santri di masa yang akan datang. c) mengembangkan kemampuan menikmati pengalaman belajar santri.

Dalam proses pembentukan karakter santri Pesantren Al-Ittihad mempunyaai aktifitas untuk menanamkan karakter yang baik serta akhlak yang mulia. Pernyataan tersebut seperti yang di kemukakan informan bahwa:

"Kegiatan di pesantren dilaksanakan dengan kegiatan yang terjadwal. Metode yang kita gunakan di pesantren salah satunya dengan menggunakan arahan, dengan pengkisahan sahabat, tokoh-tokoh islam, nahdiyin, maupun tokoh ulama. Akhirnya anak-anak dapat mencontoh dari hal yang di critakan tersebut. Setelah anak mendengar kisah-kisah tersebut, kemudian dari beberapa anak mencoba, tanpa disadari mereka mencontoh yang dicritakan. Anak yang sudah terlihat menjadi lebih baik itu menjadi contoh bagi teman- teman yang lain. Dan kita sebagai guru itu memberi motivasi kepada anak- anak yang lain agar mencontoh teman yang sudah lebih baik. Jadi apa yang dicritakan itu dapat mekangwa dampak perubahan dalam diri anak. Sehingga temanteman yang lain dapat mengikuti."

Jika pembiasan telah tertanam, maka tidak akan merasa berat bagi santri untuk menjalankan kegitan dan menjalankan tugas-tugasnya, bahkan juga akan terbiasa menjalankan ibadah agar menjadi bingkai amal ada sumber kenikmatan 
dalam kehidupannya. Karena bisa berkomunikasi langsung dengan Allah dan sesama manusia. Sebagaimana yang diungkapkan oleh Hery Noer Aly dan Munzait Saputra (2000:159) bahwasanya:

Dalam kerangka ini kegiatan-kegiatan keagamaan atau praktik-praktik keagamaan akan mempunyai nilai yang tinggi terhadap jiwa anak yang telah melakukan dan mengamalkannya. Hal itu biasanya muncul pada saat waktu sempit yang akan membuatnya mau-tidak mau harus melaksanakannya.

Menurut peneliti, hal yang di perlukan untuk membentuk karakter santri di Pesantren AlIttihad sejalan dengan konsep Muhaimin bahwa dengan danya kegiatan-kegiatan atau praktik-prakti keagamaan akan menumbuhkan sifat keterbiasaan anak untuk menjalankan dengan mudah dan selalu mempunyai inovatif-inovatif yang bagus dan menarik. Semua itu akan meningkatkan rasa senag akan kesehariannya yang selalu mereka lakukan dengan ikhlas.

Pembentukan karakter kemandirian di AlIttihad mengedepankan keteladanan dalam membentuk karakter kemandirian peserta didiknya. Setiap guru memiliki usaha yang mereka jalankan guna memberikan keteladanan kepada para peserta didik dan mempraktekkan pembelajaran mereka. Lingkungan kehidupan yang dihadapi individu sangat mempengaruhi perkembangan kepribadian seseorang, baik segisegi positif maupun negatif. Lingkungan keluarga dan masyarakat yang baik terutama dalam bidang nilai dan kebiasaan-kebiasaan hidup akan membentuk kepribadian peserta didik, dalam hal ini adalah kemandiriannya. Lingkungan sosial yang mempunyai kebiasaan yang baik dalam melaksanakan tugas-tugas di kehidupan mereka, demikian pula keadaan dalam kehidupan keluarga akan mempengaruhi perkembangan keadaan kemandirian peserta didik. Sikap orang tua yang tidak memanjakan anaknya akan menunjang perkembangan kemandirian anak. Sebaliknya anak yang dimanjakan akan mengalami kesukaran dalam hal kemandiriannya.

Pesantren Al-Ittihad berupaya membentuk dan mengembangkan karakter mandiri para santri melalui ide-ide kreatif dari para ustad dan pimpinan dan pengalamanpengalaman yang dialami langsung oleh santri. Dengan begitu, karakter mandiri ini akan memacu dan mendorong peserta didik untuk memecahkan sendiri persoalan hidup dan kehidupannya, sehingga mereka termotivasi untuk berinisiatif, berkreasi, berinovasi, proaktif, dan bekerja keras.
Pembentukan karakter religius. Karena sebagai manusia yang beriman, kita akan selalu membutuhkan Tuhan sebagai penolong kita. Dengan keyakinan bahwa Tuhan akan selalu menolong hamba-Nya yang selalu berusaha, setiap warga sekolah akan memiliki semangat yang tinggi dalam mengerjakan setiap aktivitasnya. Nilai-nilai Karakter Religius ini tertuang dalam kegiatan keseharian di AlIttihad yang dilakukan oleh warga pesantren, baik guru maupun santri. Kegiatan-kegiatan tersebut diantaranya: shalat dhuha sebelum memulai aktivitas pembelajaran; dilanjutkan dengan membaca al-Qur'an surat al-Waqi'ah setiap ba'da ashar bersama-sama; puasa sunah senin kamis. Selain itu, guru juga menganjurkan kepada santrinya untuk mengerjakan shalat tahajjud setiap malam. Nilai Karakter religius yang dibiasakan di pesantren akan menjadi kebiasaan dan tertanam pada diri peserta didik sehingga mendorong mereka untuk melakukan kebiasaan tersebut di rumah dan di manapun mereka berada.

\section{Hasil Pembentukan Karakter Santri}

\section{Pesantren Al-Ittihad}

Hasil merupakan dari hasil akhir dari suatu usaha yang telah dilakukan. Mengenai hasil dari pembentukan karakter mempunyai maksud untuk menciptakan karakter yang berakhlak mulia dan mempunyai tanggung jawab dan kejujuran dalam perkataan dan perbuatan. Hal tersebut akan merubah santri untuk mempunyai sifat, watak, tingkah laku, dan rasa tanggung jawab serta pemberani. Dalam hasil pembentukan karakter akan menumbuhkan dampak baik dalam setiap sifat dan akhlak budi pekerti yang baik.

Tujuan dari karakter Religius dan Kemandirian santri akan mempunyai tujuan agar santri mampu, (a) Memahami makna hidup, keberadaan, peranan, serta tanggung jawab di dalam berkehidupan di masyarakat, (b) Memiliki potensi dalam bidang keagamaan, (c) Mampu mengatur waktu, dan melakukan tindakan secara bijaksana, (d) Mempunyai rasa kebersamaan atau persaudaraan yang tinggi, (e) Menghormati orang tua dan guru, (f) Cinta kepada Al-Qur'an (ilmu pengetahuan) yang datang dari Allah.

Setiap manusia memiliki kebebasan, tetapi kebebasan itu harus dibatasi karena kebebasaan memiliki potensi anarkisme. Keterbatasan (ketidak bebasan) mengandung kecendrungan mematikan kreativitas, karena itu pembatasan harus dibatasi. Inilah yang dimaksud dengan kebebasan yang terpimpin. Seperti ini 
adalah watak ajaran Islam. Manusia bebas menetapkan aturan hidup tetapi dalam berbagai hal manusia menerima saja aturan yang dating dari Tuhan.

Di pesantren, santri mengatur sendiri kehidupannya menurut batasan yang diajarkan agama. Ada unsur kebebasan dan kemandirian di sini. Bahkan masing masing pesantren juga mempunyai tatacara terssendiri untuk mempunyai sebuah ciri khas dalam mendidik dan mengatur santri. Santri di sini harus mengikuti semua aturan yang telah di tetapkan oleh pesantren.

Perilaku santri mempunyai kewajiban dalam hal persaudaraan, individu harus menunaikan kewajiban terlebih dahulu, sedangkan dalam hal hak, individu harus mendahulukan kepentingan orang lain sebelum kepentingan diri sendiri. Kolektivisme itu di permudah di tebentruk oleh kesamaan dan keterbatasan fasilitas kehidupan. Selain itu jga santri mempunyai akhlak yang baik terhadap siapapun, tujuan ini dikenal antara lain melalui penegakan sebagai pranata di pesantren seperti mencium tangan guru, tidak membantah guru. Demikian juga terhadap orang tua. Nilai ini agaknya sudah banyak terkikis di sekolahsekolah umum. Dengan adanya kegiatan dalam pembentukan karakter reliogius dan kemandirian mempunyai tujuan untuk mencapai visi dan misi agar santri mempunyai jiwa karakter agamis, tanggung jawab, pemberani, bijaksana, dan jujur dan disiplin serta mempunyai akhlak mulia. Di lihat dari hasil pembentukan karakter santri Pesantren Al-Ittihad ini membuahkan hasil bahwasannya santri akan mempunyai nilai-nilai karakter yang baik. Untuk menanamkan akhlak perilaku yang baik, dan budi pekerti yang baik serta rasa pemberani dalam membela agama Islam.

Keberhasilan atau kesuksesan pada dasarnya adalah anugrah dari Allah. Bahkan untuk mencapai kesuksesan di dunia maupun di akhirat haruslah dengan mengunakan ilmu, baik ilmu agama maupun ilmu umum. Diatara haditsnya Nabi SAW yang artinya:

"Barang siapa ingin sukses didunia, hendaknya dengan ilmu. Barangsiapa ingin sukses di akhirat, hendaknya dengan ilmu. Barang siapa ingin sukses di dunia maupun akhirat, hendaknya dengan ilmu."

Dari peryataan hadits di atas bahwa orang yang ingin sukses haruslah dengan usaha agar mencapai hasil dan kesuksesan yang baik untuk bekal nantinya di dalam kehidupan akhirat. Keberasilan atau hasil dari pembentukan karakter santri akan menumbuhkan akhlak yang baik dan mulia sesuai dengan visi dan misi untuk membuat santri ber budi pekerti yang baik, selalu bertanggung jawab serta mengamalkan Fastabiqul Khoirot dan Amar Ma'ruf Nahi Munkar.

\section{PENUTUP}

Simpulan yang dapat dikemukakan dari hasil peneltian ini adalah sebagai berikut :

Peran pesantren dalam mendukung proses penanaman nilai karakter religius dan kemandirian dalam pendidikan karakter yaitu menyediakan fasilitas-fasilitas yang di gunakan untuk mendukung terlaksananya program-program yang diadakan di pesantren, memberikan izin kepada guru yang mempunyai ide untuk mengadakan suatu program kegiatan, mendukung adanya kegiatan-kegiatan yang ada di luar pesantren, serta memberikan teladan yang baik bagi siswa. 


\section{DAFTAR PUSTAKA}

Abdulloh Munir. (2010). Pendidikan Karakter: Membangun Karakter Anak Sejak dari Rumah. Yogyakarta: Pedagogia.

Agus Wibowo. (2012). Pendidikan Karakter: Strategi Membangun Karakter Bangsa Berkepribadian. Yogyakarta: Pustaka Pelajar.

Ahmad Amin. (1995). Etika (Ilmu Akhlak). Terj. oleh Farid Ma'ruf. Jakarta: Bulan Bintang. Cet. VIII.

Ahmad Toha Putra. Al-Qur'an Terjemahnya

Akmad Muhaimin Azzet. (2011) Urgensi Pendidikan karakter di Indonesia. Yogyakarta: Ar-Ruzz Media.

Akmad Muhaimin Azzet. (2011) Urgensi Pendidikan karakter di Indonesia. Yogyakarta: Ar-Ruzz Media.

Al-Ghazali. (2000). Mengobati penyakit hati terjemah Ihya' Ulum Ad-Din, dalam Tahdzib Al- Akhlaq wa Muee alajat Amradh AlQulub. Bandung: Karisma.

Asihwardji, Danuyasa, (Edt.), (1996). EnsiklopediPsikologi (Pembahasan dan Evaluasi Lengkap Berbagai Topik, Teori, Riset, dan Penemuan Baru Dalam Ilmu Psikologi), Terjemahan Ediati Kamil, Jakarta: Arcan

Darmiyanti Zuchdi. (2011). Pendidikan Karakter dalam perspektif Teori dan Praktik. Yogyakarta: UNY Press.

Darmiyanti Zuchdi. (2011). Pendidikan Karakter dalam perspektif Teori dan Praktik. Yogyakarta: UNY Press.

Darmiyati Zuchdi (2008). Humanisasi Pendidikan. Jakarta: PT. Bumi Aksara

Direktorat Jenderal Pendidikan Islam. (2006), Undang-Undang dan Peraturan Pemerintah RI tentang Pendidikan, Jakarta: Departemen Agama RI
Echlos, John M. dan Hasan Shadily. (2003.) AnEnglish-Indonesian Dictionary, Jakarta: PT. Gramedia Pustaka Utama

Fathurrohman, Ahmad, Asep. (2017) Metode Penelitian Pendidikan Agama Islam. Bandung: Kencana Utama.

Hadimulyo. (1985) Dua Pesantren Dua Wajah, dalam M. Dawam Raharjo, (ed), Pergaulan Dunia Pesantren. Jakarta: P3M

Hery Noer Aly dan Munzair Saputra. (2000). Watak Pendidikan Islam, Jakarta: Friska Agung Isnani

Husni Rahim. (2001). Pola Pembelajaran Di Pesantren . Jakarta : proyek Peningkatan Pesantren

Kemendiknas. (2010). Bahan Pelatihan : Penguatan Metodologi Pembelajaran Berdasarkan Nilai-Nilai Budaya untuk Membentuk Daya Saing dan Karakter Bangsa. Jakarta: Kemendiknas.

Kemendiknas. (2010). Bahan Pelatihan : Penguatan Metodologi Pembelajaran Berdasarkan Nilai-Nilai Budaya untuk Membentuk Daya Saing dan Karakter Bangsa. Jakarta: Kemendiknas.

Koesoema, Doni, (2007). Pendidikan Karakter, Strategi Mendidik Anak di Zaman Global, Jakarta: PT. Gramedia Widiasarana Indonesia

Lickona, T. (1991). Education for character:How our schools can teach respect and responsibility. New York: Bantam Books,

Madjid, Nurcholish. (1997). Bilik-Bilik Pesantren. Jakarta: Paramadina.

Mahmud Arif. (2008). Pendidikan Islam transformative. Yogyakarta: Lkis

Masrun, (1988). Studi Tentang Kemandirian Sebagai Kualitas Kemandirian. Makalah Seminar Ilmu-Ilmu Sosial: Mempersiapkan Masyarakat Masa Depan di Ujung Pandang

Moleong, Lexy. (2014) Metodologi Penelitian Kualitatif. Bandung: Remaja Rosdakarya. 
Muhaimin dkk (2012). Paradigma Penelitian Islam. Bandung: Remaja Rosdakarya

Muhammad Alim (2011). Pendidikan Agama Islam: Upaya Pembentukan Pemikiran dan Kepribadaian Muslim. Bandung: Remaja Rosdakarya

Mulyana, R. (2004). Mengartikulasikan Pendidikan Nilai, Bandung: Alpabeta

Mulyasa, E. (2011). Manajemen Pendidikan Karakter. Jakarta: Bumi Aksara.

Mulyasa, E. (2013). Pengembangan dan Implementasi Kurikulum 2013. Bandung: Remaja Rosdakarya

Mulyasa, E. (2018). Panduan Penulisan Tesis. Bandung: Universitas Islam Nusantara.

Narwanti, (2011). Pendidikan Karakter Penginte-grasian 18 Nilai Dalam Mata Pelajaran, Yogyaka-ta: Familia

Novan Ardy Wiyani dan barnawi. (2012) Ilmu Pendidikan Islam : Rancangan Bangun Konsep Pendidikan Monokotomik Holistik. Yogyakarta: Ar-Ruzz Media

Poerwadarminta, W.J.S. (1976). Kamus Umum Bahasa Indonesia, Jakarta: Balai Pustaka

Pusat Bahasa Departemen Pendidikan Nasional. (2008). Kamus Bahasa Indonesia. Jakarta: Pusat Bahasa. Cet. I.

Raharjo, Dawan. (1985). Pesantren dan Pembaharuan. Jakarta: LP3ES

Samsuri. (2011). Pendidikan Karakter warga Negara. Yogyakarta: Diandra

Setiawan, Marwan. (2015). Karakteristik Kriminalitas Anak dan Remaja. Bogor: Ghalia Indonesia

Soekanto, Soerjono. (2013). Sosiologi Suatu Pengantar. Jakarta: PT. RajaGrafindo Persada.

Sri Esthi Wuryani. (2002). Psikologi Pendidikan. Jakarta: Grasindo.
Surya, Hendra, (2003). Kiat Mengajak Anak Belajar dan Berprestasi. Jakarta: PT. Grasindo

Tafsir Nata, Abudin, (2001). Sejarah Pertumbuhan dan Perkembangan LembagaLembaga Pendidikan Islam di Indonesia. Jakarta: PT Grafindo persada.

Tafsir, Ahmad. (1991). Ilmu Pendidikan Dalam Persepektif Islam. Bandung : Remaja Rosda Karya.

Toto Suharto. (2011). Filsafat Pendidikan Islam. Yogyakarta: Ar-Ruz Media.

W.J.S. Poerwadarminto. (1984). Kamus Umum Bahasa Indonesia. Jakarta: PN Balai Pustaka.

Wiyani Ardy Novan dan barnawi. (2012). Ilmu Pendidikan Islam : Rancangan Bangun Konsep Pendidikan Monokotomik Holistik. Yogyakarta: Ar-Ruzz Media.

Zamak

hsyari. (1992). Tradisi Pesantren. Jakarta...

Zayadi, (2001). Desain Pendidikan Karakter, Jakarta: Kencana Pramedia Group

Zubaedi. (2011). Desain Pendidikan Karakter: Konsespsi dan Aplikasi dalam Lembaga Pendidikan. Jakarta: Kencana

Zubaedi. (2012). Desain Pendidikan Karakter Konsepsi dan Aplikasinya pada Lembaga Pendidikan Cet.II: Jakarta: Kencana.

Zuhriy, Syaifuddien. (2011). budaya pesantren dan pendidikan karakter Pada pesantren salaf. Yogyakarta: UIN Sunan Kalijaga 